\title{
Movimentos Sociais e Políticas Públicas: Consequências na Política Nacional de Direitos Humanos
}

\author{
Euzeneia Carlos $^{1}$ \\ 1Professora do Programa de Pós-Graduação em Ciências Sociais da Universidade Federal do Espírito \\ Santo (UFES). Coordenadora do Núcleo Participação e Democracia (NUPAD) da UFES e pesquisadora do \\ Núcleo Democracia e Ação Coletiva (NDAC) do CEBRAP. Vitória, ES. Brasil. \\ E-mail: euzeneiacarlos@gmail.com
}

\section{INTRODUÇÃO ${ }^{1}$}

movimento de Direitos Humanos no Espírito Santo é um caso emblemático do ativismo pelos Direitos Humanos no Brasil com consequências na Política Nacional de Direitos Humanos (PNDH). Emergente no período de redemocratização do país, na década de 1980, o movimento estadual de Direitos Humanos desenvolveu campanhas nacionais contra diversas formas de violência institucionalizadas ao longo das três décadas seguintes. Este artigo examina a Campanha Contra a Impunidade e Corrupção e a Campanha Contra as Violações no Sistema Prisional, das décadas de 1990 e 2000, e seus resultados políticos (outcomes) na formulação e implementação dos programas de proteção da PNDH, a saber: Programa de Proteção de Vítimas e Testemunhas Ameaçadas (Provita); Programa de Proteção a Crianças e Adolescentes Ameaçados de Morte (PPCAAM); e Programa de Proteção aos Defensores de Direitos Humanos (PPDDH).

O estudo é motivado por uma agenda de pesquisa internacional sobre as consequências políticas e sociais produzidas por movimentos sociais (Bosi, Giugni e Uba, 2016; Amenta et al., 2010). Aplicada a casos brasileiros, considera-se aqui a especificidade das interações entre movimentos sociais e Estado posteriores à Constituição Federal de 1988 até o impeachment de Dilma Rousseff, em 2016. Nesse período, os estudos apontam o engajamento institucional de movimentos sociais em instituições participativas e programas governamentais (Carlos, 2015a) e o 
ativismo institucional na burocracia governamental (Abers e Tatagiba, 2014), com vistas a influenciar o processo de políticas públicas (Carlos, Dowbor e Albuquerque, 2017). Baseado no pressuposto de mútua constituição entre movimento social e Estado, considera-se também a heterogeneidade deste: por um lado, sua autonomia relativa e capacidade de repressão; por outro, os pontos de acesso e encaixes institucionais construídos historicamente pelos atores em processos de interação socioestatal (Gurza Lavalle, Carlos, Dowbor e Szwako, 2019).

$\mathrm{O}$ artigo busca contribuir com a literatura especializada investigando como movimentos sociais importam para a produção de políticas públicas. Os estudos apontam diferentes tipos de efeitos de movimentos (Giugni, McAdam e Tilly, 1999), acentuando as consequências sociais, culturais, políticas, institucionais e no mercado (Bosi, Giugni e Uba, 2016). Também identificam consequências intencionais e não intencionais (Giugni, 2008). Os efeitos intencionais são aqueles diretamente ligados aos objetivos do movimento, ao passo que os não intencionais não possuem vinculação direta com as demandas do movimento, porém são percebidos como desdobramentos dele. Embora reconhecida a capacidade do movimento social de produzir mudanças políticas e sociais de cunho revolucionário, na maioria das vezes a mudança é incremental (Amenta et al., 2010; Bosi, 2016). Cumpre registrar as limitações da literatura para mensurar efeitos causais quando se trata de desenho não experimental, sendo para tanto necessária a aplicação de análises comparativas, multitemporais e casos quase experimentais (Bosi, Giugni e Uba, 2016:15-16).

Considerando esses desafios metodológicos e rejeitando qualquer tipo de causalidade permanente, a pesquisa se baseia na abordagem correlacional-processual das consequências do movimento social na política pública. A lógica de mensuração dos resultados políticos da abordagem correlacional (Bosi, 2016) consiste na correspondência entre as demandas do movimento social nas campanhas e as consequências na política setorial. Em complemento, através do rastreamento de processos ao longo do tempo - process tracing over time (McAdam e Boudet, 2012) - o artigo demonstra os eventos, episódios e processos conectando campanhas do movimento e seus resultados, convergindo na perspectiva correlacional-processual. 
Neste artigo argumento que o movimento de Direitos Humanos produziu consequências sobre a formulação e a implementação da política pública que são estruturantes da Política Nacional de Direitos Humanos. Busco defender que as campanhas do movimento social consistem em interações socioestatais que geram resultados na política pública, através de um processo de institucionalização de direitos que configura encaixes institucionais e domínio de agência. Indagando sobre as condições que favorecem os resultados alcançados, o estudo ressalta o papel dos repertórios de confronto desencadeados ao longo das campanhas, em combinação com as oportunidades e restrições políticas, e chama a atenção para os mecanismos que operam na mobilização.

Para desenvolver esses argumentos, o artigo se estrutura em quatro seções. A primeira discute a literatura sobre as consequências políticas de movimentos sociais, destacando brevemente as interações socioestatais e o papel dos repertórios de confronto nos resultados. A segunda descreve a metodologia de pesquisa. A terceira seção analisa processualmente as duas campanhas do movimento de Direitos Humanos, enfatizando no seu surgimento os objetivos e as oportunidades políticas e constrangimentos, e no seu desenvolvimento e desfecho as interações e os repertórios. Na seção seguinte, são examinados os resultados do movimento de Direitos Humanos nas decisões governamentais e na formulação e implementação dos programas de proteção da política nacional. Por fim, conclui com os principais achados e as contribuições das abordagens para o estudo das consequências de movimentos nas políticas.

\section{CONSEQUÊNCIAS DE MOVIMENTOS SOCIAIS E RESULTADOS NAS POLÍTICAS PÚBLICAS}

As consequências de movimentos sociais foram inicialmente interpretadas em termos de sucesso e fracasso. Gamson (1990) definiu sucesso como as conquistas que os movimentos alcançam através do Estado e da influência exercida nas instituições políticas. No entanto, a noção de sucesso e fracasso tendeu a ser abandonada devido à sua vagueza conceitual. Isso porque limita a consideração dos efeitos possíveis, descurando dos efeitos não intencionais ou não relacionados às intenções dos manifestantes (Amenta et al., 2010). Além disso, assume o movimento como homogêneo ao atribuir o sucesso ou fracasso para o movimento como um todo, desconsiderando as subjetividades na percepção dos resultados (Giugni, 1998). 
A maioria dos estudiosos focaram em três tipos de consequências de movimentos sociais: (i) consequências biográficas com efeitos nas trajetórias de ativistas (Giugni, 2008); (ii) mudança cultural nas normas sociais e no comportamento (Earl, 2004); e (iii) mudança política ou efeitos no contexto político e institucional (Amenta et al., 2010)2. Recentemente, os estudos sobre os efeitos de movimentos sociais ampliaram sua agenda de pesquisa, englobando as consequências sociais, culturais, institucionais, políticas e no mercado (Bosi, Giugni e Uba, 2016).

Na coletânea The Consequences of Social Movements, organizada por Bosi, Giugni e Uba (2016), as novas questões dessa agenda são distribuídas em três agrupamentos: indivíduos, instituições e políticas. No primeiro (indivíduos), além das consequências biográficas nos ativistas, os autores destacam os efeitos na população em geral, na medida em que transformando os participantes, os movimentos podem engendrar processos amplos de mudança social. Assim, associam as consequências biográficas nos ativistas às mudanças culturais na sociedade. Nessa classificação, a novidade é a inclusão dos insider activists (Banaszak, 2010), ou seja, os ativistas na burocracia pública com trajetória no movimento que podem afetar a mudança política e social criando políticas. Ou ainda, quando ativistas entram nas instituições políticas através de partidos (Rootes, 2004). Nesse agrupamento, são investigados os efeitos na ação coletiva, em enquadramentos interpretativos, discursos, táticas, organização e identidades (Polleta e Jasper, 2001; Whittier, 2004).

No segundo (instituições), são enfatizadas as consequências do movimento social na mudança institucional. As instituições podem ser estudadas como instituições formais, como a estrutura do Estado (governo, parlamento, burocracias), regime político, partidos, legislação, ou como instituições informais (regras não escritas), também em termos de normas e práticas sociais. Bosi, Giugni e Uba assinalam que a mudança institucional pode ser analisada de três formas: (i) como consequência cultural de movimentos; (ii) como mudança incremental nas relações de poder, na sequência de instituição formal e informal ou na mudança de normas; e (iii) como transformação abrupta de organizações, mudança de regimes via revoluções ou mudança política significante ou estruturante durante momentos de crise. 
As consequências de movimentos sociais na legislação se destacam na literatura, especialmente na inclusão do conteúdo da reivindicação na agenda legislativa e na aprovação de projetos de lei (Amenta et al., 2010). Nos estudos brasileiros, a criação da Lei Maria da Penha é um caso exemplar de influência do movimento feminista no Legislativo federal, por meio da inclusão de conteúdo na agenda e aprovação de projeto de lei de seu interesse (Maciel, 2011). Têm sido menos frequentes, no entanto, os trabalhos sobre os efeitos de movimentos na burocracia do Estado, nos partidos e nos regimes políticos. Ao investigar os efeitos da ecologia de movimentos nos partidos, Piccio (2016) enfatizou seus impactos discursivo e organizacional, enquanto Bosi (2016) demonstrou a complexa relação entre movimentos sociais e democratização do regime político. No caso de mudança política significante, Alonso (2014) ressalta a influência política do movimento abolicionista nacional na abolição da escravidão.

Por fim, o terceiro agrupamento (políticas) se vincula às consequências de movimentos examinadas neste artigo. $\mathrm{O}$ resultado de movimentos sociais nas políticas públicas é sobretudo examinado nos diferentes estágios da política (policy making), afetando as elites e as políticas (Bosi, Giugni e Uba, 2016). Nesse aspecto, os estudos apontam que movimento social é mais efetivo nos estágios de formação da agenda e de formulação da política, sendo menos influente nos estágios de adoção e implementação de políticas (Soule e King, 2006; Amenta et al., 2010). Os movimentos sociais influenciam a origem de políticas públicas através da especificação de alternativas que são reconhecidas pelos gestores como inovação e convertidas em instrumentos de políticas, conforme demonstrado por Dowbor, Carlos e Albuquerque (2018) em três casos: criança e adolescente; Direitos Humanos; e saúde. Ademais, Tatagiba e Teixeira (2016) identificaram os resultados do movimento de moradia na elaboração da política habitacional no município de São Paulo.

Por outro lado, alguns estudos observam a influência de movimentos no estágio de implementação, a exemplo da implementação de política ambiental, seja garantindo a execução de legislação, seja impedindo sua adoção ou programa indesejável (Rootes e Nulman, 2015). Outrossim, os estudos de Banaszak (2010) sobre as táticas do movimento feminista demonstram sua influência nos resultados das políticas para as mulheres, criando oportunidades para impactar diferentes etapas 
das políticas públicas. Desse modo, os movimentos sociais podem influenciar a implementação de políticas públicas, além da sua origem e formulação.

No estudo das consequências de movimentos sociais na política pública, a abordagem de domínios de agência oferece importante complemento, ao estabelecer uma conexão entre resultados políticos e institucionalização de direitos. Nessa abordagem, a consequência política do movimento consiste num processo de institucionalização de demandas que configuram encaixes institucionais e domínios de agência. Os encaixes significam uma "sedimentação institucional" de processos de interação socioestatal historicamente construídos entre movimentos sociais e Estado, os quais "conferem alguma agência com certa duração a determinados tipos de atores" (Gurza Lavalle, Carlos, Dowbor e Szwako 2019:49-50). Conforme argumentam os autores: "Leis, regulações, cargos e cadeiras ou vagas, órgãos e organismos, técnicas e instrumentos de políticas podem ser encaixes quando emergem como sedimentações institucionais de interações socioestatais e 'fazem' os atores agir" (2019:50). As configurações de encaixes são de diferentes tipos (variação horizontal) e diferentes níveis na hierarquia política (vertical) ou nível de autoridade onde os atores operam, os quais geram capacidades estatais na burocracia pública. Enquanto isso, os domínios de agência significam âmbitos de atuação legítimos onde é reconhecida a capacidade de agir dos atores, ou seja, suas capacidades sociais num setor específico da política pública. Ancorado no pressuposto de mútua constituição entre Estado e sociedade civil, a abordagem de domínios de agência e seu conceito de encaixe ressalta a agência de ambos (atores estatais e sociais) na produção de políticas públicas e na institucionalização de direitos.

Neste artigo, os repertórios de confronto acionados pelo movimento social são explorados enquanto condição dos resultados, em combinação com as oportunidades políticas e restrições, cujos mecanismos recorrentes definem as trajetórias das campanhas. O repertório de confronto foi definido por Tilly (2006:vii) como "conjunto de performances reivindicatórias, historicamente criada, limitada e familiar, que circunscrevem geralmente as formas pelas quais as pessoas se engajam na política contenciosa". O autor considera como elemento constituinte do repertório de confronto as interações com oponentes e aliados e as oportunidades e restrições políticas (Tilly e Tarrow, 2015). Além disso, na interação com o Estado, os movimentos sociais são ambivalentes, 
pois utilizam uma estratégia de combinação entre o conflito e a cooperação (Giugni e Passy, 1998); e combinam táticas extrainstitucional e institucional (Banaszak, 2010; Goldstone, 2003). As consequências na política pública emergem desses complexos processos de interação socioestatal construídos ao longo do tempo, em cuja dinâmica o movimento acumula aprendizado, acessos no Estado e colaboração com atores e instituições.

\section{METODOLOGIA DE PESQUISA}

O Movimento de Direitos Humanos do Espírito Santo (MDH-ES) foi examinado ao longo de duas décadas (anos 1990 e 2000), no intuito de aferir suas consequências na política pública, especialmente nos programas de proteção da PNDH. A pesquisa empírica ${ }^{3}$ introduziu a "campanha" como unidade de análise de movimento social ${ }^{4}$. A campanha é um momento de visibilidade pública da ação do movimento social, formada por um conjunto de eventos e episódios com sequenciamento concatenados e constituintes do processo de ação coletiva (Tilly, 2006). É um esforço público sustentado de elaboração de reivindicações coletivas direcionadas a determinadas autoridades (Tilly, 2010). Definir campanha como unidade de análise permite apreender o movimento social em seu processo de ação no continuum temporal, quando há um objetivo político claro que define a construção de identidades compartilhadas, a escolha de repertórios e performances e a formação de redes de ativismos e coalizões.

As campanhas do MDH-ES, em sua origem vinculadas a campanhas nacionais, lograram repercussão internacional, cada uma delas se prolongando por quase uma década. São elas: 1) Campanha Contra a Impunidade e Corrupção (1993 a 2002); e 2) Campanha Contra as

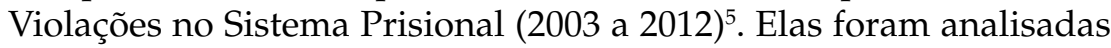
por meio de documentos de época ${ }^{6}$ do movimento e de entrevistas em profundidade com ativistas ${ }^{7}$. As informações das diversas fontes foram processadas com auxílio do software NVivo Pro 11, e trianguladas com vistas à validação das evidências em linhas convergentes de investigação. A reconstrução longitudinal da sequência de episódios, eventos e interações ao longo de cada campanha conduziu aos processos de ação coletiva, com ênfase em três momentos concatenados - emergência, pico e desfecho. 
O estudo de caso em profundidade e análise longitudinal possibilitou o rastreamento de processos ao longo do tempo (McAdam e Boudet, 2012), garantindo maior precisão na correlação entre os objetivos políticos da campanha e as consequências nas políticas (Bosi, 2016). Através dessa perspectiva correlacional-processual (combinação entre abordagem correlacional e process tracing) é demonstrado como as campanhas do movimento geraram resultados na política de Direitos Humanos, sobressaindo a vantagem do método para analisar consequências políticas.

\section{AS CAMPANHAS DO MOVIMENTO DE DIREITOS HUMANOS: CONDIÇÕES E MECANISMOS}

Quais condições favorecem as consequências políticas do movimento social? Nesta seção ressalto o papel dos repertórios de confronto desencadeados nas campanhas, em combinação com as oportunidades políticas e restrições do contexto de emergência. Neste processo, identifico alguns mecanismos recorrentes no confronto político ao longo do tempo, ou seja, dinâmicas sociais que ocorrem numa variedade de situações e contextos (Tilly, 2006). São eles: o mecanismo cognitivo de "atribuição coletiva de ameaça e oportunidade" e os mecanismos de inovação nos repertórios como a "adaptação", a "certificação" e a "difusão" (Tilly, 2005).

\subsection{Campanha Contra a Impunidade e Corrupção (1993 a 2002)}

No dia 19 de agosto de 1993, foi lançada a Campanha Nacional Contra a Impunidade na cidade de Vitória, no Espírito Santo. A campanha foi criada pelo Movimento Nacional de Direitos Humanos (MNDH), a partir de suas bases no MDH-ES articulado no MNDH-Regional Leste I e no Centro de Defesa de Direitos Humanos da Serra (CDDH). Na sua emergência, congregou em ações coordenadas cerca de 40 entidades estaduais (organizações de movimentos, entidades religiosas, sindicatos trabalhistas, ONGs e ativistas), promotoras do Fórum das Entidades do Campo e da Cidade e do Fórum Contra a Violência em Defesa da Vida (Carlos, 2015a).

As denúncias de crime organizado infiltrado nas instituições do Estado e de atuação de grupos de extermínio foram as principais motivações para emergência da campanha. Seu objetivo político se vinculava à 
uma situação notável de impunidade, corrupção e violência, expressa nos assassinatos impunes de ativistas e lideranças partidárias e sindicais, no extermínio de crianças e adolescentes e um grande número de homicídios encobertos e sem investigação policial. Associado à ação dos grupos de extermínio, a campanha clamava pelo combate ao crime organizado penetrado: "no Executivo, envolvendo prefeitos e policiais militares, no Legislativo através da corrupção de deputados e funcionários da Assembleia Legislativa, e nos órgãos de fiscalização e accountability como o Tribunal de Contas" (Souza, 2014:48).

Nessa campanha, a corrupção aparece vinculada à luta contra a impunidade, sendo essa um recurso de acobertamento das práticas corruptoras. A campanha nacional que começa contra a impunidade logo se torna uma luta contra a violência e a corrupção como traços daquela, consideradas elemento violador dos Direitos Humanos. Os oponentes eram claramente percebidos como instalados nas instituições do Estado, com ramificações na sociedade através da violência institucionalizada nos grupos de extermínio.

\section{Oportunidades Políticas e Restrições}

As oportunidades e restrições políticas envolvem um elemento subjetivo, pois cognitivamente percebidas pelos desafiantes podem reduzir os custos da ação coletiva e incentivar a mobilização (Tarrow, 2009; Della Porta, 2014). A "atribuição coletiva de ameaça e oportunidade" é um mecanismo cognitivo crucial na mobilização (Tilly e Tarrow, 2007:95). Foram fundamentais na emergência da campanha três fatores das oportunidades políticas ${ }^{8}$. Primeiro, a percepção dos ativistas de nacionalização da causa impulsionada por eventos de repercussão nacional: (i) a realização do seminário "Violência e Extermínio de Crianças e Adolescentes", ocorrido na Assembleia Legislativa do Espírito Santo (ALES), no dia 10 de abril de 1991, a fim de cobrar soluções das autoridades. Organizado por diversas entidades civis, como o Movimento Nacional de Meninos e Meninas de Rua de Vitória (MNMMR) e a Pastoral do Menor da Arquidiocese de Vitória, o seminário também reuniu o Judiciário e parlamentares (Xavier, 2014:90); (ii) a visita do Papa João Paulo II a Vitória, em 19 de outubro de 1991, com entrega de carta-denúncia ao Pontífice pelas entidades da sociedade civil reunidas no recém-criado Fórum das Entidades do Campo e da Cidade. A denúncia externava com indignação a atuação do crime organizado e de grupos de extermínio; e (iii) a divulgação de matérias jornalísticas na mídia 
nacional e estadual de grande circulação sobre o extermínio de crianças e adolescentes, dando visibilidade pública ao quadro de violência e impunidade. Baseadas em denúncias do MDH-ES, do MNMMR, do Movimento de Defesa dos Direitos das Crianças e Adolescentes e da Pastoral do Menor da Arquidiocese de Vitória, os crimes de extermínio chegaram às manchetes dos jornais em 1990 e testemunhas anônimas denunciaram 76 assassinatos sem investigação policial ${ }^{9}$. A tortura e assassinato de crianças e adolescentes também reverberou na mídia ${ }^{10}$ : "entre 1991 e 1993, mais de 30 meninos e meninas de rua em Vitória foram mortos" (Xavier, 2014:87).

Em segundo lugar, a percepção dos ativistas de abertura institucional através de: (i) instalação da Comissão de Processos Administrativos Especiais (CPAE) pelo governador Albuíno Azeredo (PDT), em 05/09/1991 ${ }^{11}$, para investigação das denúncias de extermínio e crime organizado; (ii) abertura de inquérito policial para apuração da infiltração do crime organizado nas instituições do estado, pelo delegado de Polícia Civil Francisco Vicente Badenes Júnior, em 1992; e (iii) criação do Conselho Estadual da Criança e do Adolescente (CRIAD, Lei Estadual N. 4521/91) e da Comissão de Direitos Humanos e Cidadania na ALES, em 1992. Por fim, houve ainda a percepção coletiva de elites políticas aliadas nas instituições: no Legislativo Estadual, através da eleição de parlamentares do Partido dos Trabalhadores (PT) ${ }^{12}$; no Congresso Nacional, através de deputados federais do $\mathrm{PT}^{13}$ e do Partido Democrático Trabalhista (PDT); e na delegacia da Polícia Civil no Espírito Santo.

A instalação da CPAE culminou na identificação das bases de sustentação do crime organizado nas instituições do estado (Executivo, Legislativo e Judiciário) e na sociedade (SDLC e Esquadrão da Morte, União Democrática Ruralista-UDR e máfia do jogo de bicho) ${ }^{14}$. A CPAE produziu "dossiês e relatórios sobre a violência, a corrupção e a impunidade no estado que embasaram a realização de audiências com autoridades para denúncia e cobrança de providências" (Carlos, 2015:234) ${ }^{15}$. A relação entre impunidade, corrupção e crime organizado fora aí estabelecida. As ações de extermínio eram atribuídas a organizações criminosas como a Organização Pena de Morte (OPM) e Scuderie Detetive Le Cocq (SDLC) ${ }^{16}$, e vinculadas ao crime organizado. A SDLC agia como "personificação jurídica do crime organizado e 
quartel de grupos paramilitares de extermínio" (Ministério da Justiça, 2002:s / p). Em 2000, o relatório da CPI do Narcotráfico da Câmara Federal elucidou que a SDLC

\begin{abstract}
incorpora, em seus quadros de associados, centenas de policiais (civis, militares e federais), serventuários da justiça, delegados, advogados" (...) funcionários da administração pública, promotores de justiça e até juízes de direito, desembargadores, políticos, empresários, comerciantes [e banqueiro do jogo do bicho] (Justiça Global, 2002:7).
\end{abstract}

Por seu turno, a atribuição coletiva de restrições políticas e ameaças também compuseram o quadro cognitivo dos ativistas e impulsionaram a emergência da campanha. De acordo com a classificação de Petersen e Wahlström (2015), dois fatores restritivos se destacam na campanha. Primeiro, a dimensão institucional da repressão exercida contra atores coletivos desafiantes das relações de poder existentes: censura, confisco de evidências, obstrução de investigação criminal e extinção de comissões investigativas. E, segundo, a dimensão funcional que varia de formas sutis de repressão (subtle forms), através de intimidação e violência simbólica, à coerção violenta no outro extremo do espectro, a saber: (i) ameaças, perseguição, estigmatização e intimidação sofridas por ativistas e membros da CPAE em retaliação às investigações realizadas (Human Rights Watch, 1994) ${ }^{17}$; (ii) assassinato de ativistas de Direitos Humanos e lideranças sindicais cujos crimes foram atribuídos à SDLC (Justiça Global, 2002) ${ }^{18}$. O relatório da Justiça Global totalizou mais de 10 casos de ameaças, intimidações e pressões institucionais contra membros da sociedade civil, legislativo e executivo, poder judiciário, ministério público e delegados de polícia, além de 13 assassinatos por motivação política no período da campanha.

Conforme defendem Petersen e Wahlström (2015), a repressão pode ser bem-sucedida em conter a dissidência doméstica ou, ao contrário, levar a uma escalada da indignação pública e mobilização. As restrições políticas e ameaças às ações dos ativistas resultaram na expansão da mobilização social, ao contrário da sua subjugação, impulsionando a emergência da campanha. Desse modo, a repressão expressa em impedimentos institucionais e funcionais, cognitivamente percebida como ameaça, opera como mecanismo que impulsiona a ação coletiva, porque aumenta a percepção de alto custo da inação. 
Interações Socioestatais e Repertórios de Confronto

O confronto entre o movimento de Direitos Humanos e o governo estadual fora acirrado ao longo da campanha, perpassando as gestões de Albuíno Azeredo (PDT, 1991-1994), Vitor Buaiz (PT, depois PV, 1995-1998) e José Ignácio Ferreira (PSDB, 1999-2002). O acirramento se agravou no governo José Ignácio Ferreira, com a ameaça de fechamento do Conselho Estadual de Direitos Humanos, em 1999 (Carvalho, $2014)^{19}$. Nesse mesmo ano, o Espírito Santo ficou nacionalmente conhecido como "mar de lamas", noticiado pela mídia IstoÉ Independente, decorrente do indiciamento do governador José Ignácio Ferreira pelo Ministério Público Federal (MPF) como partícipe direto de esquemas de corrupção ${ }^{20}$. É nesse momento que se dá o adensamento das mobilizações sociais e o pico da campanha.

Ao longo daquela década, a relação Executivo-Legislativo estadual marcada por barganha em torno de abertura de Comissão Parlamentar de Inquérito (CPI) e pedido de impeachment do governador, de disputas por cargos públicos e atos de corrupção - deu sustentação à perpetuação do crime organizado (Tavares, 2004). Sob a influência política do deputado José Carlos Gratz (PFL), empresário do "jogo de bicho" que ocupou a presidência da ALES por três mandatos consecutivos (1996 a 2002), firmou-se uma política de alianças no Legislativo com os governadores (idem) ${ }^{21}$.

As relações entre o movimento social e o Estado configuraram dois padrões de interação socioestatal - conflitivo e cooperação conflitual (Carlos, 2015a; 2017) - acionados circunstancialmente ao longo da campanha ${ }^{22}$. Esses subjazem à escolha dos repertórios de confronto, seja extrainstitucional, seja institucional, seja ainda multiescalar, desencadeados em face das oportunidades e restrições políticas. Pelo padrão de interação conflitivo o movimento social aciona repertórios extrainstitucionais que prescindem de aderência ou apoio de setores do Estado. Por sua vez, a cooperação conflitual consiste no uso de repertórios institucionais que acionam o apoio de instituições e elites políticas aliadas, ao mesmo tempo que mantém a atitude de contestação na relação com o Estado. Isso significa que a escolha por repertórios institucionais não necessariamente representa a ausência de conflito; ao contrário, significou o uso de estratégias institucionalizadas para contestar o poder do Estado, a exemplo da cooperação com atores do Legislativo e do sistema de justiça. Por seu 
turno, através do repertório multiescalar a tática de nacionalização e internacionalização da causa é acionada pelo movimento em face dos constrangimentos na arena doméstica.

Os repertórios de confronto são explorados como condição que facilita os resultados políticos. Neles, são identificados alguns mecanismos que operam no processo de inovação nas táticas e performances, a saber, o mecanismo de "adaptação" e de "certificação". Segundo Tilly (2006), a inovação conjuga a continuidade do repertório existente em alguma medida, sendo um continuum de inovação e modulação.

O movimento de Direitos Humanos notabilizou-se pela sua capacidade organizativa, de posicionamento político e de investigação independente. A combinação entre repertório extrainstitucional, institucional e multiescalar num mesmo confronto político foi a sua maior inovação. O repertório extrainstitucional, predominante ao longo da campanha, reúne as iniciativas do movimento formadas por diversas táticas e performances. Em ordem decrescente de citação, são elas: relatório; banco de dados; dossiê; denúncia; fórum; divulgação na mídia; ato público; apelo; carta aberta; manifesto; nota de repúdio; passeata; e vigília. A principal tática do movimento foi a elaboração de documentos que comprovam por meio de evidências a violação de Direitos Humanos, através de relatórios, dossiês e banco de dados que fundamentam suas denúncias às autoridades. Essa produção coletiva de informações possui um duplo sentido para os ativistas: (a) funcionar como enquadramento interpretativo do movimento acerca das injustiças sociais, suas origens, consequências e soluções; e (b) conferir visibilidade política, social e moral às injustiças até então encobertas pelo Estado, sociedade ou mídia.

Ao longo da campanha o movimento produziu cerca de 20 volumosos documentos (dentre relatórios, dossiês, banco de dados e coletânea, excluídas atas, cartas, manifestos e notas de repúdio), concentrados em dois períodos, na emergência e no pico da campanha. Os relatórios sobre inquéritos policiais de apuração de grupos de extermínio, crimes insolúveis e casos de impunidade contribuíram para construção pública da causa durante a gênese e primeiros anos da campanha (1989 a 1994); enquanto os dossiês, relatórios e coleções sobre o crime organizado sinalizavam para o prognóstico do problema já no pico e desfecho da campanha (1999 a 2004) ${ }^{23}$. 
No movimento de Direitos Humanos, a denúncia fundada em relatórios e dossiês é uma "performance modular" (Tarrow, 2009) alimentada por experimentos pretéritos, aprendizados e saberes acumulados ao longo da trajetória ${ }^{24}$. Além de modulação houve inovação no repertório através de uma "inovação tática": o Banco de Dados Sobre Violência: Perfil dos homicídios no ES, que catalogou os homicídios e a dinâmica da violência local por quase uma década (1994 a 2001) ${ }^{25}$. Essa inovação foi motivada pelo não acesso ou inexistência de estatísticas, mapas e levantamentos nos órgãos estatais de justiça e segurança pública a respeito da violência. $\mathrm{O}$ cruzamento de informações de diversas fontes jornalísticas permitiu um diagnóstico mais complexo sobre a violência no ES, condensadas em relatórios anuais, um resultado notável dado que as estatísticas criminais da Polícia Civil e da Polícia Militar não eram integradas.

O repertório de fórum também consiste numa inovação na forma organizacional do movimento, ao invés da escolha do formato de associações, entidades civis ou ONGs. A campanha criou a inovação organizacional do fórum no próposito de articular as várias forças sociais e políticas em torno da causa da violência e da impunidade, caracterizado por coordenação colegiada e liderança descentralizada. Além das redes de ativismo do movimento social, o novo formato agregou as coalizões de apoio reunindo numa mesma forma organizacional as entidades da sociedade civil, grupos religiosos, sindicatos trabalhistas e partidos políticos de esquerda. Isso se materializou na criação do Fórum de Entidades do Campo e da Cidade e do Fórum Permanente Contra a Violência em Defesa da Vida, em 1992, na emergência da campanha. Já no pico da campanha, em 1999, houve uma "adaptação" dessa inovação organizacional através da criação do Fórum Permanente Contra a Violência e a Impunidade - Fórum Reage Espírito Santo. Esse fórum adaptou a inovação produzida antes via adição de atores e conexões locais, a exemplo da Ordem dos Advogados do Brasil (OAB-ES) e do Ministério Público na formação de coalizão ampla de apoio à causa, num momento de densidade da mobilização.

Com maior capacidade de visibilidade pública e de mobilização social, embora menos frequentes, são as manifestações e protestos como as passeatas, caminhadas e atos públicos. As passeatas ocorreram desde o início da campanha, sobretudo motivadas pelo extermínio de crianças e adolescentes, como a passeata em Vitória ocorrida três dias após o assassinato do ativista Jean do MNMMR, performatizada com sím- 
bolos e os menores encapuzados por medo de represália policial. Mas foi no pico da campanha que os protestos alcançaram maior poder de mobilização, quando o nexo entre impunidade e corrupção alcançou a mídia. Por exemplo, a passeata que mobilizou 8 mil pessoas, em Vitória, em 1999, e a Caminhada pela Paz que reuniu 2 mil participantes, em 2000. Os protestos foram acompanhados de atos públicos e performances simbólicas em frente ao Tribunal de Justiça e ao Tribunal de Contas nesse último, com a lavagem da escadaria que aludia à corrupção e às práticas criminosas quanto às contas públicas. Outro protesto de grande projeção foi a Caminhada contra a Corrupção e Crime, cujo local de encerramento foi o Tribunal de Justiça.

Por sua vez, no repertório institucional se destacam as táticas colaborativas do movimento com atores estatais e instituições com pontos de acesso àqueles. Em ordem decrescente de menção: abertura de CPI; relatórios; diagnósticos e denúncias conduzidas por órgãos públicos apoiadores; pedido de intervenção federal; petição pública; reuniões com autoridades; participação em conselhos e audiências públicas; ação civil pública; lobby; e ocupação de cargos ${ }^{26}$. Nos primeiros anos da campanha foi de grande repercussão a ação civil pública impetrada pelo MPF, em 1996, pela dissolução da SDLC. Essa foi antecedida pelo dossiê da CPAE presidida pelo delegado Badenes sobre a SDLC e o crime organizado e seu "relatório de ameaças à Comissão", ambos de 1993; e pelo "Dossiê Gabriel Maire" da Comissão Permanente de Defesa da Cidadania e Direitos Humanos da ALES, de 1994.

No pico da campanha e de criação do Fórum Reage ES destacou-se a abertura de várias CPIs, relevante no prognóstico da campanha. A mais importante foi a CPI do Narcotráfico da Câmara Federal, instalada de 1999 a 2000, que confirmou as denúncias de ações do crime organizado ${ }^{27}$ Os ativistas do movimento colaboraram nas investigações com depoimentos e evidências, agindo na confecção dos relatórios, dossiês e ação civil pública. Também cooperaram na elaboração do pedido de Intervenção Federal no Espírito Santo, em 2002, compondo a comissão debatedora da intervenção federal. O pedido foi impetrado pela OAB-ES, junto ao Conselho de Defesa dos Direitos da Pessoa Humana (CDDPH) do Ministério da Justiça (MJ). O relatório da CDDPH recomendou a intervenção federal no estado, sendo acatada pelo MJ. Porém, o pedido foi negado pelo então presidente da República, Fernando Henrique Cardoso (PSDB) ${ }^{28}$, que alternativamente enviou uma Missão Especial ao ES para apuração das denúncias ${ }^{29}$. 
Por fim, o repertório multiescalar consiste em performances de nacionalização e internacionalização da causa, uma inovação tática no repertório de confronto do movimento. Diante da percepção de esgotamento das estratégias de pressão na arena doméstica, essa inovação visa à ressonância nas esferas nacional e internacional na qual opera o mecanismo de "certificação", ou seja, ao reconhecimento por parte de autoridade externa das reivindicações de um ator político.

A nacionalização da campanha ocorreu no ápice da mobilização, através: (i) do acionamento de agências públicas federais; e (ii) da ressonância na mídia nacional. No primeiro caso, com o pedido de inclusão do Espírito Santo na CPI do Narcotráfico da Câmara Federal ${ }^{30} \mathrm{e}$ do pedido de intervenção federal. Além disso, em 2003, o Fórum Reage ES encaminhou um relatório-denúncia para o Supremo Tribunal Federal (STF), cobrando ações mais contundentes do MPF e do Ministério Público Estadual (MPE), da Polícia Federal e da CPI do Narcotráfico da Câmara Federal. No segundo caso, as investigações da CPI do Narcotráfico e sua repercussão no desmonte do crime organizado alcançaram audiência na mídia nacional, com matéria na IstoÉ Independente, em $2001^{31}$. Em 2003, no desfecho da campanha, a relação do crime organizado com o Legislativo e Executivo Estadual teve cobertura nos jornais $A$ Gazeta e $A$ Tribuna. A reverberação na mídia foi importante tanto na emergência quanto no pico da campanha, momento de êxito nas consequências políticas.

Em acréscimo, através da tática de internacionalização da campanha, o movimento acionou as organizações intergovernamentais de Direitos Humanos em defesa da causa. Isso ocorreu em 2002, mediante denúncia à Organização dos Estados Americanos (OEA), em audiência da Comissão Interamericana de Direitos Humanos (CIDH), em Washington, intermediada pela ONG Justiça Global. O relatório-denúncia entregue à OEA, elaborado pela Justiça Global com a colaboração do MDH-ES e Fórum Reage ES, expôs as graves violações aos Direitos Humanos, a atuação de grupos de extermínio, os casos de impunidade e a negligência do Estado diante de diversas denúncias, bem como sua vinculação ao crime organizado. Pari passu a ressonância da campanha, nacionalmente e internacionalmente, houve retaliações, perseguições, ameaças e assassinatos ${ }^{32}$. Muitos ativistas e deputados apoiadores da campanha solicitaram proteção judicial (Justiça Global, 2002). 


\subsection{Campanha Contra as Violações no Sistema Prisional (2003 a 2012)}

A emergência da Campanha Contra as Violações no Sistema Prisional no Espírito Santo deu-se em 2003, motivada pelo lançamento da Campanha Nacional Permanente Contra Tortura, promovida pelo MNDH em colaboração com a Secretaria Especial dos Direitos Humanos da Presidência da República (SEDH-PR). Desenvolvida de 2001 a 2003, a campanha nacional foi antecedida pela assinatura do Pacto Nacional Contra a Tortura, firmado em 2000. A campanha enquadrou os casos de "tortura institucional" e os associou às agências de Segurança Pública, como as secretarias estaduais de Justiça responsáveis pela administração carcerária e as polícias civil e militar (MNDH, 2003:6). Um desdobramento da campanha nacional foi a criação de sedes estaduais para monitoramento dos casos de tortura, a exemplo do Comitê Estadual para a Prevenção e Erradicação da Tortura (CEPET). No Espírito Santo, a campanha foi promovida por organizações do movimento de Direitos Humanos (MNDH, CDDH Serra, $\mathrm{CADH}^{33}$ e Justiça Global), organizações religiosas (Pastoral do Menor e Pastoral Carcerária da Arquidiocese de Vitória) e órgãos colegiados como o CEDH.

O objetivo político da campanha foi a defesa dos direitos dos sujeitos privados de liberdade em oposição à "violência ilegal do Estado", esse percebido como responsável pelos "tratamentos cruéis e degradantes" nas unidades prisionais e de internação socioeducativa. As denúncias de violência institucionalizada se reportavam principalmente aos estabelecimentos penais, intensificadas no interstício de 2006 a 2010 (CEDH, 2011a). Conforme atestou o relatório da ONG Justiça Global, em cinco anos a população carcerária adulta do ES dobrou, sempre mantendo um déficit de vagas, saltando de 5.125, em 2005, para 10.803, em 2010 (Justiça Global et al., 2011). As constantes denúncias de tortura, esquartejamento, superlotação e outras violações aos presos, conduzidas por organizações de Direitos Humanos e conselhos às autoridades públicas revelavam um sistema calamitoso que foi comparado nos inúmeros relatórios e diligências aos "campos de concentração nazista" e às "masmorras da Idade Média". As violações nas prisões (presídios, DPJs, micro-ônibus e contêineres ${ }^{34}$ ) se estendiam às Unidades de Internação Sócioeducativa (Unis), conforme constatou o Conselho Nacional dos Direitos da Criança e do Adolescente (Conanda), após denúncias de tortura e morte de adolescentes encaminhadas pelo movimento (Carlos, 2015:239). Para os ativistas, as violações no sistema prisional vão além de uma situação conjuntural 
associada a um único governo ou coligação partidária: ao contrário, remetem às estruturas do Estado e da sociedade. Os oponentes são identificados no Estado, nas instituições de Justiça e órgãos de Segurança Pública aos quais dirigem seus clamores.

\section{Oportunidades Políticas e Restrições}

No surgimento da campanha no Espírito Santo alguns fatores percebidos pelos ativistas como oportunidades e restrições políticas assumiram importante papel, concernente ao mecanismo cognitivo de "atribuição coletiva de ameaça e oportunidade". Nas oportunidades políticas, destaca-se, em primeiro lugar, a abertura institucional na esfera federal, com a assinatura do Pacto Nacional Contra a Tortura (2000), seguida do lançamento da Campanha Nacional Permanente Contra Tortura (2001) e do incentivo da SEDH-PR às ações locais de monitoramento e denúncias dos casos de tortura institucional. A campanha nacional tinha como propósito a sua continuidade através de ações conjuntas no nível local (CEDH, 2011a). No âmbito estadual, a abertura institucional foi percebida pela assinatura do Pacto Estadual de Erradicação dos Crimes de Tortura, em 13 de dezembro de 2004, entre organizações do MDH-ES, entidades da sociedade civil e representantes governamentais. Ela doi seguida pela realização do Seminário de Discussão da Lei da Tortura e pela criação do CEPET estadual. A regularidade no funcionamento do CEDH é igualmente percebida pelos ativistas como oportunidade para emergência na campanha.

Em segundo lugar, a percepção de elites políticas aliadas nos três poderes também consiste em importante fator, sobretudo no nível federal: no Ministério Público Federal; no Legislativo Federal; no Executivo Federal (SEDH-PR, MJ, Conanda e CDDPH); e no Executivo Estadual (NDH-SEJUS e CEDH).

Por sua vez, a percepção coletiva de constrangimentos políticos ou ameaças compuseram o quadro cognitivo dos ativistas. Nesse caso, consistiu em repressão do Estado caracterizada por repressão governamental às ações ativistas nos aspectos institucional e funcional (Petersen e Wahlström, 2015). No primeiro aspecto, no impedimento institucional de investigação das violações, proibição de visitação aos presídios e unidades socioeducativas, censura e confisco de evidências. Essas medidas repressoras do governo estadual ocorreram em 2006, após as inspeções do sistema penitenciário pelo Conselho Nacional 
de Justiça (CNJ), pela Comissão de Direitos Humanos e Minorias da Câmara Federal e pelo CDDPH, que confirmaram a situação caótica dos presídios e deram base para o MJ pedir a intervenção federal no ES. O pedido de intervenção foi negado pelo presidente Luiz Inácio Lula da Silva (PT) e, no mesmo ano, o sistema carcerário sofreu um colapso, com rebeliões simultâneas nas prisões ${ }^{35}$. Concatenado às rebeliões nos presídios houve ataques incendiários a ônibus nas cidades, coordenados pelos detentos articulados com grupos de fora das prisões.

Por fim, o aspecto funcional da repressão reside na imposição de formas sutis e simbólicas, sintetizadas em iniciativas governamentais de criminalização de ativistas e movimentos sociais, deslegitimação da causa, perseguição, intimidação, retaliação, estigmatização, calúnia, grampeamento telefônico ilegal, inquérito policial indevido e ameaça de morte. Ativistas foram acusados pelo governo estadual de subverterem a ordem, orquestrarem as rebeliões nos presídios e os ataques incendiários a ônibus na cidade ${ }^{36}$. Porém, a repressão governamental e as ameaças cognitivamente percebidas pelos ativistas, ao contrário de conter a dissidência, aumentaram a indignação e impulsionaram a ação coletiva. A repressão governamental incentivou a emergência da campanha, operando como um mecanismo ou gatilho deflagrador da indignação coletiva, em virtude da percepção coletiva de alto custo da inação.

\section{Repertórios de Confronto e Redes de Interação}

A campanha contra as violações do sistema prisional se estendeu por quase uma década, tendo seu ápice em 2009 e 2010. Sua emergência, desenvolvimento e desfecho ocorreram integralmente no governo Paulo Hartung (PMDB), ao longo de dois mandatos consecutivos (2003-2011). Segundo Ribeiro Junior (2011), a falta de infraestrutura mínima e tratamentos adequados nas prisões foram agravados pela "política de encarceramento em massa", resultante da reformulação da política penitenciária e de segurança pública pelo governo Hartung ${ }^{37}$.

Ao longo do período, as relações entre movimento social e Estado configuraram dois padrões (conflitivo e cooperação conflitual), reproduzindo as interações socioestatais da Campanha da Impunidade. $\mathrm{O}$ movimento combinou os três repertórios de confronto da campanha pretérita, embora com inovações nas táticas e performances. Os reper- 
tórios extrainstitucional, institucional e multiescalar foram circunstancialmente combinados ao longo do tempo, conferindo modularidade à inovação antes forjada.

O repertório extrainstitucional foi composto sobretudo por denúncia, visitação, ato público e divulgação na mídia, além de vigília, passeata, ocupação, paralisação, fiscalização, apelo e abaixo-assinado. A principal inovação tática foram as visitações às prisões e às Unis, por meio das quais os ativistas estabeleceram contato direto com os sujeitos privados de liberdade e averiguaram as violações. As visitações permitiram desvelar os casos de tortura e esquartejamento através de depoimentos dos presos ${ }^{38}$, e embasaram as denúncias do $\mathrm{CEDH}$ ao $\mathrm{MJ}$, que inspecionou o sistema prisional em 2006.

Foi em torno das ações de visitação que se deu o acirramento do conflito com o governo estadual, que resultou em sua proibição pelo longo período de 2006 até 2009. A proibição da visitação dos presídios e unidades socioeducativas se dirigia às organizações de Direitos Humanos como CEDH, Pastoral Carcerária e Pastoral do Menor, com as quais o governador se recusava ao diálogo. Também se dirigia aos órgãos oficiais, cuja vistoria e diligência foram coibidas ou condicionadas a um regramento específico determinado pela SEJUS, com o impedimento do contato direto com os presos e do registro em imagem e áudio. Porém, nesse interstício, as denúncias de violações se intensificaram, fazendo-se chegar ao CEPET e ao NDH-SEJUS, na maioria das vezes pelas mães, familiares e amigos dos presos, por meio de depoimento individual ou pela Associação de Mães e Familiares de Vítimas de Violência (AMAFAVVI).

As visitações foram autorizadas, em 2009, mediante decisão judicial demandada pelo CEDH. A permissão às visitações intensificou a campanha e inaugurou seu pico de mobilização, que se estendeu até 2010. Retomadas num ritmo crescente, as visitações contabilizaram 14 eventos no período, ascendendo a onda de mobilizações. Ao mesmo tempo, se exacerbaram as denúncias e os relatórios mais contundentes, a exemplo do relatório coletivo do CEDH, CDDH Serra, Justiça Global e Conectas Direitos Humanos, e do relatório da AMAFAVVI, ambos de 2011. 
Por sua vez, através do repertório institucional setores do Estado foram acionados pelo movimento. Ações institucionais junto a órgãos governamentais, parlamentares federais e partes do Judiciário foram empregadas, como a colaboração na produção de relatórios, diligências, CPI e denúncias das autoridades, reuniões de cobrança e audiências públicas, além de lobby e petição pública. As inspeções, diligências e relatórios de órgãos do governo federal confirmavam as violações no sistema prisional. No relatório da CPI da Câmara dos Deputados, em 2009, as condições degradantes do sistema prisional capixaba foram apontadas como o principal fator das rebeliões nos presídios e do desaparecimento de detentos das unidades. Tal cenário "revelou a ausência de ação estatal no sistema prisional, que violava os Direitos Humanos", conforme expressou um ativista (CEDH, 2011b:26).

Finalmente, o repertório multiescalar de nacionalização e internacionalização da causa foi performatizado em diferentes ações e incrementado pelo aprendizado da campanha pretérita. A nacionalização da campanha ocorreu no ápice da mobilização, especialmente com a CPI da Câmara Federal que apurou as diligências nos presídios capixabas, em 2009. No mesmo ano, conferiu visibilidade nacional à campanha o relatório do Conselho Nacional de Política Criminal e Penitenciária (CNPCP) do MJ, bem como o relatório de violações da Conectas Direitos Humanos.

Mas o auge da campanha deu-se com a sua internacionalização, com as denúncias às organizações intergovernamentais de Direitos Humanos. Nas táticas transescalares, a articulação com ONGs internacionais de Direitos Humanos foi crucial, como Justiça Global e Conectas Direitos Humanos, cuja intermediação possibilitou a chegada das denúncias à ONU e à OEA. No dia 15 de março de 2010, as violações foram denunciadas na ONU, pelo depoimento de um ativista do MDH-ES em Genebra, Suíça ${ }^{39}$, no painel "Direitos Humanos no Brasil: violações no sistema prisional - o caso do Espírito Santo", durante a $13^{\text {a }}$ Sessão do Conselho de Direitos Humanos da ONU (Justiça Global et al., 2011). A iniciativa foi formalizada coletivamente pela Conectas Direitos Humanos, CADH, CDDH Serra, CEDH, Justiça Global e Pastoral do Menor. Logo depois, em 19 de março de 2010, foram denunciadas na audiência pública temática sobre o sistema prisional brasileiro, promovida pela OEA em Washington, onde participaram a Justiça Global e a Pastoral Carcerária Nacional. Na audiência pública, se somaram às denúncias do movimento os depoimentos de Deputados Federais 
que atuaram na CPI que investigou o sistema carcerário nacional de 2007 a 2008. Paralelamente às denúncias na ONU e OEA, ocorreram manifestações, passeatas, paralisações, vigília e ocupação do prédio da SEJUS, em Vitória, promovidas pelo MDH.

O papel da mídia alçou destaque na internacionalização da campanha, com a coluna de Elio Gaspari às vésperas da denúncia à $\mathrm{ONU}$, na qual o sistema prisional ficou conhecido como "as masmorras capixabas". A notícia baseou-se em denúncia conduzida por um ativista do movimento de Direitos Humanos, publicada no jornal O Globo no dia 7 de março de 2010 e, no dia anterior, censurada no jornal local A Tribuna ${ }^{40}$.

A inovação reside na ativação da performance multiescalar através do mecanismo de difusão, adotando a tática da campanha pretérita e acrescentando outro tema, arenas e redes de ativismo. Além disso, registra-se a recorrência do mecanismo de certificação, que conferiu reconhecimento externo à reivindicação coletiva. Na difusão da tática de internacionalização de uma campanha à outra, o movimento inovou via adição de novo tema (tortura), rede de intermediação (Conectas Direitos Humanos) e nova arena internacional (ONU). A ação multiescalar passou a ser um repertório modular do movimento de Direitos Humanos, cuja inovação tática se originou na campanha contra a impunidade.

\section{CONSEQUÊNCIAS DO MOVIMENTO SOCIAL NA POLÍTICA PÚBLICA DE DIREITOS HUMANOS}

O movimento de Direitos Humanos, por meio de campanhas de mobilização ao longo dos anos 1990 e 2000, produziu resultados na política pública que configuram encaixes institucionais e domínios de agência voltados à institucionalização de demandas. A maioria das consequências políticas do movimento é incremental como a incidência nas decisões governamentais, mas também significante ou estruturante na produção de política pública, a exemplo da formulação e implementação dos programas de proteção da Política Nacional de Direitos Humanos.

A partir de abordagem correlacional-processual, o estudo identificou a correspondência entre as decisões governamentais e os objetivos defendidos pelo movimento em campanhas de abrangência nacional. Na Campanha Contra a Impunidade e Corrupção, o movimento influenciou as decisões de autoridades públicas, imbuído pela decisão 
política de investigar as denúncias de grupos de extermínio e crime organizado que levou, em 1995, à Representação para Fim de Dissolução da SDLC, pelo delegado de polícia responsável pelas investigações e, em 1996, à Ação Civil Pública de Dissolução da SDLC do MPF, além da inclusão do ES na CPI do Narcotráfico da Câmara Federal, em 2000, e da instalação da Missão Especial de Combate ao Crime Organizado do MJ, em 2002. Em decorrência dessas medidas, ocorreram a condenação de agentes públicos envolvidos com o crime organizado e a dissolução da SDLC, respectivamente em 2000 e 2004, enquanto efeitos intencionais da campanha.

Essa campanha, ao deflagrar a fragilidade da burocracia estatal na segurança pública (homicídios, crimes insolúveis ou sem investigação e testemunhas ameaçadas) e nos Direitos Humanos (extermínio de crianças e adolescentes, lideranças políticas e ativistas), influenciou a decisão governamental pela criação de novos órgãos, cargos e instrumentos de políticas. Por exemplo, em 1997, na gestão do governador Vitor Buaiz, a criação do Núcleo de Direitos Humanos (NDH) na SEJUC (atual SEJUS) e do CEDH; a ocupação de cargos por ativistas de Direitos Humanos; e a incorporação do "Banco de Dados Sobre Violência: Perfil dos Homicídios no ES" na administração pública como instrumento de política, inicialmente operacionalizado no NDH em parceria com o MDH e o NEVI-UFES.

Importa destacar que o Banco de Dados Sobre Violência é uma inovação originária do movimento social que foi reconhecida pelo governo estadual como alternativa de política e instrumentalizada no setor de segurança pública. Em 2004, o banco de dados foi convertido no Centro Integrado Operacional de Defesa Social (CIODES), durante o primeiro governo Paulo Hartung, tornando-se um marco na instrumentação da política de segurança pública. O CIODES consiste num banco de dados integrado de informações criminais no governo estadual, agregando as fontes de órgãos da segurança pública como Polícia Militar, Polícia Civil, Corpo de Bombeiros Militar, Guarda Civil municipal de Vitória, Secretaria de Justiça, Polícia Rodoviária Federal e Secretaria Estadual de Saúde (SESA). Conforme demonstrado alhures, as políticas setoriais podem ter origem "movimentista", quando instrumentos de políticas adotados pelos governos possuem sua gênese em inovações produzidas por movimentos sociais, e reconhecidas pelos tomadores de decisões como alternativas de políticas (Dowbor, Carlos, Albuquerque, 2018). 
Por seu turno, na Campanha Contra as Violações no Sistema Prisional, as consequências nas decisões governamentais equivalem às medidas de reestruturação da infraestrutura dos presídios, estabelecimentos de prisão provisória e unidades socioeducativas, em 2010: desativação dos complexos modulares (celas contêineres de Novo Horizonte, na Serra), reforma nas Unis e construção de novas unidades, redução da lotação nos DPJs e construção de CDPs e centros de triagem (Justiça Global et $a l ., 2011)$. Essas consequências nas decisões governamentais são associadas aos objetivos políticos do movimento no início da campanha, tornadas perceptíveis no final do pico de mobilização com a nacionalização e internacionalização da causa. Como efeitos intencionais, visavam incidir sobre as violações no sistema de encarceramento dos presos e daqueles sob o regime socioeducativo ${ }^{41}$. Tais decisões políticas foram resultantes de medidas cautelares ao Estado brasileiro, interpostas por organismos internacionais de Direitos Humanos (ONU e OEA), em ação coordenada entre organizações do movimento (CEDH, CDDH Serra, CADH, Pastoral Carcerária e Pastoral do Menor) e ONGs internacionais de Direitos Humanos (Conectas Direitos Humanos e Justiça Global), durante a campanha ${ }^{42}$.

Resta destacar a consequência da campanha sobre a decisão política de criação de órgãos públicos, ampliando a burocracia governamental na produção da política de Direitos Humanos. Por exemplo, a criação de órgãos e cargos na política setorial: a formalização do CEPET através da Lei Estadual no 10.006, de 26 de abril de 2013, em funcionamento desde 2004, cuja mudança incremental na sequência de instituição informal à formal elevou seu grau de institucionalização; a criação da Subsecretaria de Direitos Humanos (SUBDH) acoplada à Secretaria Estadual de Assistência Social e Direitos Humanos (SEADH), em 2011, no governo Renato Casagrande (PSB, 2011-2014); e a criação da Secretaria Estadual de Direitos Humanos (SEDH-ES), em 2016, no terceiro mandato de Paulo Hartung (2015-2018). Além disso, o movimento influenciou a decisão governamental de elaboração do Plano Estadual de Direitos Humanos (PeDH) e do Plano Estadual de Educação em Direitos Humanos (PeEDH), no âmbito do PNDH-III ${ }^{43}$. Para construção do PeDH e PeEDH foi instituído um Grupo de Trabalho pelo Decreto 2244-R, de 9 de janeiro de 2012, formado por diversas entidades da sociedade civil e do Estado, sob a coordenação do CEDH e da SUBDH-SEADH ${ }^{44}$. 
Os resultados do movimento de Direitos Humanos, além de incremental nas decisões governamentais geraram consequências estruturantes sobre a formulação e a implementação da política setorial, particularmente nos programas de proteção e promoção dos Direitos Humanos que integram o núcleo da Política Nacional de Direitos Humanos (PNDH) ${ }^{45}$. São eles: o Programa de Proteção de Vítimas e Testemunhas Ameaçadas (Provita); o Programa de Proteção a Crianças e Adolescentes Ameaçados de Morte (PPCAAM); e o Programa de Proteção aos Defensores de Direitos Humanos (PPDDH). Esse é o principal resultado político das campanhas do movimento social, pois os programas de proteção foram centrais: (a) na estruturação da política nacional; (b) na sua institucionalização ao longo do tempo; e (c) na construção da legitimidade dos grupos vulnerabilizados pelas violações no enquadramento dos Direitos Humanos. Isso significa que as consequências do movimento social na política de Direitos Humanos, além de incremental, pode ser estruturante da política pública.

O primeiro programa criado, Provita (um dos tripés da PNDH), teve sua gênese no Espírito Santo onde foi pioneiramente implantado, em 1998, na gestão Vitor Buaiz, institucionalizado no ano seguinte através da Lei 9.807 de 13 de junho de 1999. O Provita foi criado como instrumento de enfrentamento à criminalidade e à impunidade, em face da ação de grupos de extermínio e do crime organizado no ES, oferecendo proteção às testemunhas, vítimas ou réus-colaboradores de processos jurídicos (Bezerra, 2009). A relação entre a origem do Provita e a campanha da impunidade é inconteste, com base em evidências documentais e entrevistas ${ }^{46}$. Nas palavras de uma ativista do movimento de Direitos Humanos:

O Espírito Santo embora seja um estado pequeno em dimensões territoriais, ele tem uma sociedade civil muito ativa, né, militantes de Direitos Humanos muito ativos que não se calam, não têm medo, e aí a gente tem uma gama, né, que foram assassinados, que isso tem que tá gravado na nossa história. Por conta disso tudo é um dos motivos que o Provita vem, por conta do grande número de impunidade e o alto número de violência. O Provita vem por conta de tudo isso que a gente vivenciou. É crime organizado, grupo de extermínio, Esquadrão da Morte e essa campanha que jogou luz em cima de um problema que a população vivenciava (Entrevista 12, em 15 de março de 2017). 
Logo depois, o Provita tornou-se política de Estado como parte da PNDH através do Decreto Federal 3.528/2000 da Secretaria de Direitos Humanos da Presidência da República (SDH/PR), no governo Fernando Henrique Cardoso. Além de influenciar a origem e a formulação do programa, o movimento de Direitos Humanos produziu resultados sobre a sua implementação, através da sua execução pelo $\mathrm{CADH}$, prolongando-se até os dias atuais.

O segundo programa instituído foi o PPCAAM, também de iniciativa pioneira no ES, criado no ano de 2003 pelo governo federal de Luiz Inácio Lula da Silva. Foi oficialmente instituído em 2007, pelo Decreto 6.231/07. No Espírito Santo, o PPCAAM foi implementado desde o ano de sua criação (2003), também com a execução pelo CADH em parceria com a SDH/PR (depois SEDH/PR). No âmbito estadual foi inicialmente vinculado à Setades ${ }^{47} \mathrm{e}$, atualmente, integra o Sistema Estadual a Vítimas e Testemunhas da SEDH-ES. Até o ano 2000, os casos de violação que envolviam crianças e adolescentes vítimas ou testemunhas eram encaminhados ao Provita (Brasil, 2010). O PPCAAM se especializou na proteção desse segmento em face dos processos de vitimização e vulnerabilidade de crianças e adolescentes à violência letal, sendo um desdobramento do Provita.

Por fim, o terceiro programa de proteção associado aos objetivos políticos das campanhas é o PPDDH. No âmbito federal, o Programa Nacional de Defensores dos Direitos Humanos foi criado em 2004, na SEDH/PR, com o intuito de proteger pessoas ameaçadas por sua atuação na defesa de direitos (Natalino et al., 2009). Foi regulamentado pelo Decreto 6.044, de 12 de fevereiro de 2007, que instituiu a Política Nacional de Proteção aos Defensores de Direitos Humanos. No Espírito Santo, o contexto de repressão e ameaças ao exercício do ativismo durante a campanha contra a impunidade influenciou a criação do PPDDH. Esse foi formalizado através da Lei 8.233/2005, da Assembleia Legislativa, que instituiu o PEPDDH (Programa Estadual de Proteção aos Defensores de Direitos Humanos) e instalou sua coordenação no CDDH Serra, sendo atualmente implementado pelo CADH. Conforme visto, o ativismo de Direitos Humanos fora exercido sob diversas formas de repressão, variando de subtle forms, através de intimidação, perseguição, retaliação, proibição e violência simbólica até coerção violenta, por meio de inquérito policial, ameaças de morte e assassinatos. Cabe ressaltar que, em 2002, o relatório da Justiça Global e do Fórum Reage ES, ao enfocar as ameaças, intimidações e pressões institucionais 
contra membros da sociedade civil e da sociedade política ao longo da campanha, recomendou "a aplicação dos princípios da Declaração das Nações Unidas sobre Defensores dos Direitos Humanos", de 1999 (p.15), ou seja, antes mesmo do programa nacional ser instituído. $\mathrm{O}$ fato converge com estudos que apontam que o programa nacional é fruto de intensa mobilização da sociedade civil e da incorporação pelo Estado das normas internacionais para proteção dos Direitos Humanos e das recomendações da ONU e OEA (Brasil, 2014).

\section{Encaixes Institucionais e Domínio de Agência na Política de Direitos Humanos}

Neste artigo, defendo que as consequências políticas do movimento social consistem num processo de institucionalização de demandas em direitos, muitas das quais configuram encaixes institucionais e domínio de agência na promoção dos Direitos Humanos. Na abordagem de domínios de agência, os instrumentos de políticas como leis, regulações, órgãos, cargos, programas e planos configuram encaixes quando emergem como sedimentações institucionais resultantes de interações socioestatais, historicamente construídas com vistas à institucionalização de direitos (Gurza Lavalle, Carlos, Dowbor e Szwako, 2019). Esse é o caso do movimento de Direitos Humanos no Espírito Santo, que, ao longo de duas décadas de campanhas nacionais, construiu encaixes institucionais de diferentes tipos (variação horizontal) e níveis de hierarquia política ou autoridade em que operam (variação vertical), com vistas a influenciar a política pública.

As consequências das campanhas que configuram encaixes institucionais, remetendo à sua variação horizontal, correspondem a dois tipos principais. Primeiro, a criação de órgãos de Direitos Humanos (NDH, CEDH, CEPET, SUBDH, SEDH-ES) e de Segurança Pública (CIODES) no governo estadual, ao longo do período de 1997 a 2016. Acoplado aos órgãos de Direitos Humanos, a criação de novos cargos e a sua ocupação por ativistas de Direitos Humanos ${ }^{48}$ também consiste em encaixe que favorece o acesso ao Estado e às instituições ${ }^{49}$. Segundo, a criação de planos como o PeDH e o PeEDH, nos idos de 2012 e 2013, e a formulação e implementação de programas de proteção de Direitos Humanos (Provita, PPCAAM e PPDDH), no período de 1998 até os dias atuais, no âmbito do Sistema Estadual de Direitos Humanos e da Política Nacional de Direitos Humanos da Presidência da República. Em resumo, esses órgãos, cargos, planos e programas são consequências, na política pública, que configuram encaixes institucio- 
nais, arquitetados ao longo das campanhas de Direitos Humanos. Os encaixes também variam hierarquicamente ou no nível de autoridade em que operam (variação vertical). Enquanto os órgãos, cargos e planos operam no nível de autoridade estadual, os programas de proteção atingem, além da estadual, uma escala superior de hierarquia política - a federal. Como enfatizado, o pioneirismo do ES na produção dos programas de proteção (Provita, PPCAAM e PPDDH), seguido pela criação em outros estados da federação com histórico de violações similares e a criação dos programas em nível nacional, gerou consequências estruturantes na PNDH. Nesse caso, a alta hierarquia política do encaixe elevou seu grau de institucionalização, transformando-o em direito à proteção pelo Estado. A criação desses órgãos públicos e programas de proteção engendrou capacidades estatais na burocracia governamental, em vista da política de Direitos Humanos. A Figura 1 apresenta na linha do tempo a construção de encaixes (1997 a 2016), seus diferentes tipos e níveis de hierarquia política no continuum temporal das campanhas.

Figura 1

Encaixes Institucionais ao Longo do Tempo (1997 a 2016): Tipos e Hierarquias

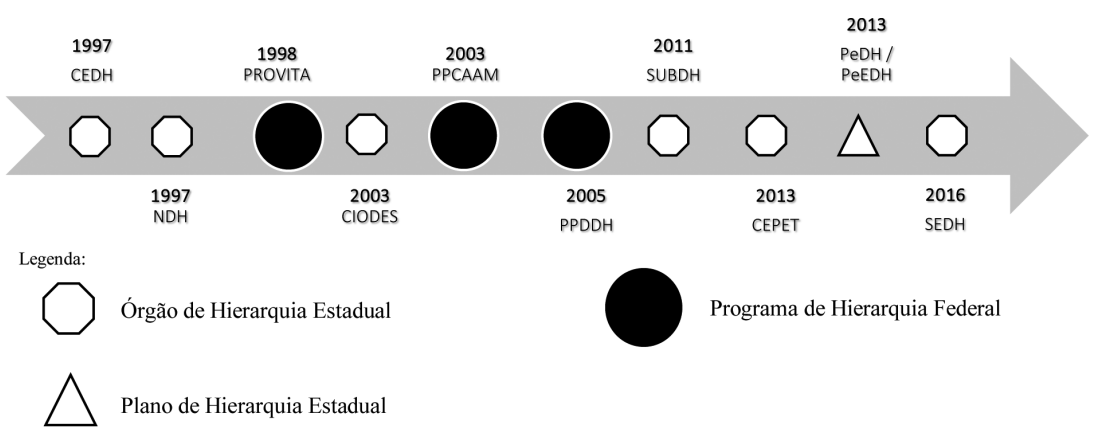

Fonte: Elaboração própria com base na pesquisa desenvolvida neste artigo.

A análise processual das campanhas ao longo do tempo permitiu identificar os encaixes institucionais dentre as consequências políticas. Os encaixes preexistentes operam como recurso que potencializa a construção de novos encaixes e acessos no Estado, cujo acúmulo presume o aprendizado dos atores de um processo a outro. Conceber os resultados na política pública como encaixes significa assumir que são derivados de processos de interação socioestatal construídos historicamente, cujos atores estatais e sociais são politicamente relevantes e mutuamente constituídos. 
As configurações de encaixes (tipos e autoridades) se articulam em domínios de agência, âmbitos de atuação legítimos em que é reconhecida a capacidade de agir dos atores sociais na proteção dos Direitos Humanos. Os domínios de agência conferem capacidades sociais aos atores coletivos num setor específico e, particularmente nesse caso, em que o Estado e seus agentes são os violadores e as capacidades estatais são insuficientes para operar a política de Direitos Humanos. Nas campanhas do movimento de Direitos Humanos, o CADH e CDDH-Serra desenvolveram domínios de agência (habilidades e capacidades sociais) nesse setor de política, se especializando na implementação de programas de proteção de Direitos Humanos. Especialmente o CADH tem ampliado o reconhecimento de seu domínio de agência para além do nível estadual, incidindo sobre a autoridade política nacional através da interlocução com os programas nacionais de proteção da PNDH. Outrossim, na esfera internacional, o CADH foi reconhecido como comenda da OEA e da ONU e lhe foi atribuído o "status consultivo especial" pela ONU, atestando seu domínio de agência em questões relativas à proteção e à promoção dos Direitos Humanos.

Este estudo defende que a especificação dos encaixes institucionais em diferentes tipos e níveis de autoridade contribuiu para compreensão das consequências políticas do movimento social, indo além da noção de sucesso e fracasso, em direção a uma tipologia dos resultados na política pública. Mas não somente. A abordagem de domínios de agência ao assimilar os resultados nas políticas como encaixes enfatiza as interações socioestatais subjacentes, e contribui para a compreensão do processo de institucionalização de demandas em direitos ao longo do tempo. Isso aperfeiçoa o enfoque correlacional de outcomes, tornando-o mais processual na explicação dos resultados políticos. O pressuposto de mútua constituição entre Estado e sociedade civil permite explorar como a interação entre as duas esferas constitui reciprocamente as capacidades estatais e sociais. Em última instância, esta abordagem de consequências políticas contribui para a análise da institucionalização de demandas do movimento em direitos de cidadania, reconstruindo ao longo do tempo os processos de mobilização e de institucionalização. 


\section{CONCLUSÕES}

O movimento de Direitos Humanos produziu consequências sobre a formulação e a implementação dos programas de proteção (Provita, PPCAAM e PPDDH) ininterruptamente por mais de duas décadas que são estruturantes da Política Nacional de Direitos Humanos, além de resultados incrementais na política pública, ao influenciar as decisões governamentais de criação de órgãos, cargos, legislação, normativas e planos na burocracia do setor. Do ponto de vista da mudança institucional, isso significa que a consequência política do movimento social pode expressar uma mudança significante na política pública, além de incremental.

A consequência do movimento social na política pública consiste num processo de institucionalização de direitos ao longo do tempo. A conexão entre resultados políticos e institucionalização de demandas se estabelece na abordagem de domínio de agência, que oferece importante complemento aos estudos de outcomes a partir de perspectiva processual e mutuamente constitutiva das relações entre Estado e sociedade civil. As consequências nas políticas públicas quando configuram encaixes e domínio de agência são capazes de forjar capacidades estatais na burocracia pública e capacidades sociais na promoção dos Direitos Humanos. Particularmente relativo aos programas de proteção, alçou uma elevada autoridade política que habilitou os atores sociais à influência na política nacional, ascendendo o grau de institucionalização das demandas e convertendo-as em direitos.

Adicionalmente, o artigo explorou as condições e mecanismos que favorecem os resultados políticos, como o papel dos repertórios de confronto ao longo das campanhas, em combinação com as oportunidades políticas e as restrições ao ativismo. A capacidade de aprendizado, de inovação nas táticas e de combinação entre múltiplos repertórios habilitou o movimento social a incidir na política pública. Isso, associado à sua habilidade de articulação de redes de ativismos na sociedade civil, e de coalizões com atores e instituições políticas.

(Recebido para publicação em 13 de janeiro de 2020)

(Reapresentado em 22 de maio de 2020)

(Aprovado para publicação em 23 de setembro de 2020) 


\section{NOTAS}

1. Este artigo é resultado do pós-doutorado no Centro Brasileiro de Análise e Planejamento (Cebrap), com estágio no Center of Social Movements Studies da Scuola Normale Superiore, em Florença, Itália, realizado com o auxílio da Fundação de Apoio à Pesquisa e Inovação do Espírito Santo (Fapes, Edital 12/2018). Agradeço a Angela Alonso e Debora Maciel pelos comentários às versões preliminares, e aos pareceristas anônimos da Revista Dados.

2. Para uma revisão ampliada da literatura internacional sobre os efeitos de movimentos sociais e os modelos explicativos de suas consequências políticas, vide: Carlos, Dowbor e Albuquerque (2017).

3. Realizada com auxílio do Conselho Nacional de Desenvolvimento Científico e Tecnológico (CNPq), Edital Universal 14/2014, e da Fapes, Edital Universal 06/2014. Agradeço a Monika Dowbor e Maria do Carmo Albuquerque pela colaboração na pesquisa.

4. Movimentos sociais são definidos como coletividades formadas por uma rede de interações informais entre uma pluralidade de indivíduos, grupos e/ou organizações, engajados em um conflito político ou cultural, com base em identidades compartilhadas (Diani, 2003).

5. Essas campanhas foram as principais do período em termos de mobilização, continuidade no tempo, capacidade de ressonância e de resultados políticos, a despeito de outras ações pontuais do movimento.

6. Os documentos de época foram coletados no acervo de organizações do MDH, perfazendo 90 arquivos e o total de 2.757 páginas. As fontes documentais foram classificadas por tipo (relatório, reportagem, ata, projeto, carta, revista, manifesto, nota pública e relato), origem (sociedade civil, Estado e mídia) e momento da campanha (emergência, pico e desfecho).

7. As entrevistas em profundidade foram aplicadas para dezesseis ativistas de organizações do movimento que atuaram nas campanhas, com base em roteiro semiestruturado. Foram concedidas à autora e realizadas entre agosto de 2016 a abril de 2017, com uma média de duas horas de duração cada, gravadas em áudio e transcritas na íntegra. Em todos os produtos da pesquisa mantém-se o anonimato dos(as) ativistas entrevistados(as).

8. Oportunidade política são quaisquer mudanças percebidas que alteram a relação de poder entre Estado e movimento social (Tarrow, 2009).

9. Cf. A Gazeta, 02/09/1990, 04/09/1990.

10. Cf. A Tribuna, 14/11/1990, 29/03/1991.

11. Decreto 4.887-ES.

12. À época, haviam recém-assumido os mandatos de deputados estaduais na ALES, pelo PT: Claudio Vereza, Iriny Lopes, Brice Bragato e Aloizio Krohling, parlamentares com trajetórias políticas no movimento de Direitos Humanos.

13. Domingos Dutra (PT-MA) e a deputada federal Benedita da Silva (PT-RJ).

14. MNDH/CDDH/Fórum das Entidades do Campo e da Cidade, 1994. 
15. Logo após a divulgação do dossiê, o governador Albuíno Azeredo dissolveu a CPAE, em 17/08/1993 pelo Decreto 6.097, dias antes do lançamento nacional da campanha.

16. A SDLC foi criada oficialmente no Espírito Santo, em 1984, com existência também no Rio de Janeiro.

17. O relatório da CPAE (1993b) registrou que muitos detetives que atuaram na comissão pediram transferência após ameaças, como o promotor Manoel Antônio de Barros, em 1993. Além do delegado da Polícia Civil Francisco Badenes que sofreu ameaças, intimidação, perseguição, estigmatização, rebaixamento e transferência.

18. Na emergência da campanha, foram de grande repercussão os assassinatos de ativistas de Direitos Humanos, como do padre Gabriel Maire, em 23/12/1989, do líder sindical e ativista do Movimento de Trabalhadores Sem Terra (MST) Valdício Barbosa dos Santos, em 12/09/1989, do ativista do MNMMR Jean Alves da Cunha, em 12/11/1992, e do ambientalista Paulo Cesar Vinha, em 28/04/1993.

19. O CEDH foi criado pela Lei 5.165, de 19 de dezembro de 1995, no início do governo de Vitor Buaiz, em grande medida devido a ação de ativistas na Secretaria Estadual de Justiça e Cidadania (SEJUC), como Perly Cipriano (PT) e de deputados estaduais do PT (Souza, 2014).

20. "Lambança capixaba" (IstoÉ, 22 de setembro de 1999). Vide também "Encurralados" (IstoÉ, 1999).

21. Segundo Tavares (2004:59), a aliança de Gratz com os governadores, que se inicia na segunda metade do governo Albuíno, foi interrompida com a eleição de Buaiz, mas recuperou fôlego na segunda metade de seu governo com o apoio à candidatura do deputado à presidência da ALES e consequente rompimento com o PT, prolongando-se pelo governo José Ignácio.

22. Para uma análise aprofundada da combinação entre o padrão de interação conflitivo e de cooperação conflitual no MDH-ES, vide Carlos (2014).

23. Cf. Principais relatórios de autoria do MDH-ES (1989, 1991, 1994, 1999, 2000, 2001, 2002, 2003, 2004).

24. "Modular", pois as mesmas formas (organização de associações e sindicatos, manifestações públicas, greves, passeatas, comícios, reuniões) podem servir a variados lugares, atores e assuntos (Alonso, 2012:27).

25. A criação do Banco de Dados Sobre Violência foi deliberada pelo CDDH Serra e MNDH, em janeiro de 1994, como estratégia da campanha no levantamento de informações sobre a violência. Sua metodologia de coleta e análise dos dados jornalísticos sobre os homicídios foi desenvolvida em parceria entre essas organizações do movimento e o Núcleo de Estudos, Pesquisa e Extensão sobre Violência, Segurança Pública e Direitos Humanos (NEVI) da Universidade Federal do Espírito Santo (UFES).

26. Sobre a ocupação de cargos como tática de movimentos sociais, vide: Dowbor (2012) e Abers, Serafim e Tatagiba (2014).

27. Em 2001, a CPI do Narcotráfico denunciou o deputado Gratz, dentre outros deputados estaduais, e um desembargador por envolvimento com o crime organizado, a SDLC e o 
jogo de bicho. Também denunciou promotores, advogados, juízes, delegados de polícia, policiais militares e civis pela ligação com crime organizado.

28. Sendo o presidente do mesmo partido do governador, o desfecho do caso chegou à opinião pública da mídia nacional e instalou uma crise política no governo federal que levou a exoneração a pedido do ministro da justiça Miguel Reale Júnior (Teixeira, 2004:70).

29. Durante a Missão Especial, muitas figuras públicas investigadas foram desmoralizadas e Gratz teve seu mandato cassado.

30. Depoimento da ativista do movimento (Entrevista 13, em 15/03/2017).

31. "O He-Man capixaba" (08/08/2001); "Capo capixaba" (01/08/2001); “Imóveis suspeitos" (25/07/2001); “Golpe baixo" (11/07/2001).

32. Assassinato do advogado Joaquim Marcelo Denadai, membro da CPAE, em 2002, e do Juiz Alexandre Martins de Castro Filho, responsável pela Missão Especial, em 2003.

33. O CADH foi criado em 2001, com a extinção do antigo MNDH-Regional Leste I.

34. Os contêineres ou celas metálicas foram apelidados de "micro-ondas" porque chegavam a $52^{\circ} \mathrm{C}$ ao longo do dia, resultantes da política estadual de criação de vagas nas prisões através de presídios modulares para servirem de centros de detenção provisória e permanente (AMAFAVV, 2011).

35. Depoimento do ativista do movimento (Entrevista 6, em 20/11/2016 e 14/12/2016).

36. Depoimento da ativista do movimento (Entrevista 16, em 10/04/2017).

37. Na avaliação de ativistas, havia certa unanimidade em torno da política de segurança pública e de encarceramento do governo Hartung, evidenciada nos seus apoios na ALES, no Judiciário e no MPE.

38. Depoimento do ativista do movimento (Entrevista 15, em 24/03/2017).

39. Depoimento do ativista do movimento (Entrevista 14, em 16/03/2017).

40. Intitulada "As masmorras de Hartung aparecerão na ONU". Depoimento do ativista do movimento (Entrevista 6, em 20/11/16 e em 14/12/2016).

41. Cabe destacar um provável efeito não intencional indesejável, ou seja, contraditório à causa da campanha, como o recrudescimento da tutela de adultos e adolescentes, com o aumento do uso de aparatos de segurança e medidas punitivas dentro do sistema, como os Regimes Disciplinares Diferenciados (RDDs), acompanhado da ausência de um projeto pedagógico para reinserção social (cf. AMAFAVV, 2011).

42. A CIDH-OEA reconheceu a situação de extremo risco em que viviam os internos das unidades prisionais e socioeducativas. A medida cautelar também exigiu que o governo reduzisse consideravelmente a superpopulação carcerária, evitasse a transmissão de doenças contagiosas no interior da prisão e garantisse aos presos acesso a cuidados médicos. De acordo com a Justiça Global (2011), desde então as organizações de direitos humanos passaram a monitorar o cumprimento dessas medidas cautelares pelo governo brasileiro e o capixaba. 
43. A aprovação da terceira versão do Programa Nacional de Direitos Humanos (PNDH III) ocorreu em 2009, após a XI Conferência Nacional de Direitos Humanos. Para uma visão da longa trajetória de elaboração das três versões do PNDH e suas diferenças fundamentais, vide: Natalino et al., 2009.

44. A versão final do PeDH e PeEDH foi aprovada em 29/11/2013 e publicada em 04/04/2014.

45. No âmbito federal, a questão dos direitos humanos se vinculou a promoção e a defesa de grupos específicos. Ao lado de temas já tradicionais como desaparecidos políticos e setores da política externa foi agregada questões sociais das minorias, dos riscos sociais e das violações de direitos (Natalino et al., 2009:106).

46. Cf. "Projeto do Programa de Orientação a Vítimas de Violência", elaborado pelo MDH-ES, indicativo da gênese do Provita.

47. Secretaria de Trabalho, Assistência e Desenvolvimento Social do Estado do Espírito Santo.

48. A ocupação de cargos no executivo estadual por ativistas de Direitos Humanos deu início no governo Victor Buaiz, com Perly Cipriano na condição de secretário estadual da SEJUC e Ana Caracoche na coordenação do NDH (SEJUC, depois SEJUS), tendo ela permanecido até a segunda gestão de Paulo Hartung. No governo Renato Casagrande, a SUBDH (SEADH) esteve sob a gestão dos ativistas Helder Salomão e Perly Cipriano. Além da ocupação de cargos no executivo estadual, Perly Cipriano e Iriny Lopes assumiram posições de alto escalão na burocracia pública do Ministério de Direitos Humanos, durante os governos Lula (2003-2010).

49. A ocupação de cargos públicos por ativistas de movimentos sociais foi nomeada por Banaszak (2010) de "activism insider" e por Abers e Tatagiba (2014) de "ativismo institucional". 


\section{REFERÊNCIAS}

ABERS, Rebecca; SERAFIM, Lizandra; TATAGIBA, Luciana. (2014), “Repertórios de Interação Estado-Sociedade em um Estado Heterogêneo: A Experiência da Era Lula”. Dados, vol. 57, n 2 , pp. 325-357.

ABERS, Rebecca; TATAGIBA, Tatagiba. (2014), "Institutional Activism: Mobilizing for Women's Health from inside the Brazilian Bureaucracy". Anais do $38^{\circ}$ Encontro Anual da Anpocs, Caxambu.

ALONSO, Angela. (2014), “O Abolicionismo como Movimento Social”. Novos Estudos, n 100, pp. 115-137.

AMENTA, Edwin; CAREN, Neal; CHIARELLO, Elizabeth; SU, Yang. (2010), "The Political Consequences of Social Movements". Annual Review of Sociology, vol. 36, pp. 287-307.

BANASZAK, Lee Ann. (2010), The Women's Movement Inside and Outside the State. Cambridge, Cambridge University Press.

BEZERRA. Verônica Cunha. (2009), A Contribuição Efetiva dos Programas de Proteção no Combate da Impunidade: Um Olhar a Partir da Experiência do Provita/ES - Os Aspectos Jurídicos desta Prática. Especialização em Direitos Humanos. Universidade Católica de Brasília Virtual, Brasília.

BOSI, Lorenzo. (2016), “Incorporation and Democratization: The Long-Term Process of Institutionalization of the Northern Ireland Civil Rights Movement", in L. Bosi, M. Giugni e K. Uba (eds.), The Consequences of Social Movements. Cambridge, Cambridge University Press, pp. 338-360.

; GIUGNI, Marco; UBA, Katrin. (2016), "The Consequences of Social Movements: Taking Stock and Looking Forward", in L. Bosi, M. Giugni e K. Uba (eds.), The Consequences of Social Movements. Cambridge, Cambridge University Press, pp. 3-38.

CARLOS, Euzeneia. (2017), "Cooperação e Conflito na Relação Movimentos Sociais e Estado”. Política \& Sociedade, vol. 16, n 35, pp. 321-350.

(2015a), Movimentos Sociais e Instituições Participativas: Efeitos do Engajamento Institucional no Contexto Pós-Transição. Belo Horizonte, Fino Traço.

(2015b), “Movimentos Sociais e Instituições Participativas: Efeitos do Engajamento Institucional nos Padrões de Ação Coletiva". Revista Brasileira de Ciências Sociais, vol. $30, \mathrm{n}^{\circ} 88$, pp. 83-99.

(2014), "Mudanças e Continuidades no Movimento de Direitos Humanos: Padrões Organizacionais, Relacionais e Discursivos". Opinião Pública, vol. 20, n 3, pp. 450-479.

; DOWBOR, Monika; ALBUQUERQUE, Maria do Carmo. (2017), “Movimentos Sociais e seus Efeitos nas Políticas Públicas: Balanço do Debate e Proposições Analíticas". Civitas, vol. 17, n 2, pp. 360-378.

CARVALHO, Paulo. (2014), Fórum Reage Espírito Santo: Relações entre Sociedade Civil e Estado de 1999 a 2006. Monografia (Graduação em Ciências Sociais), Universidade Federal do Espírito Santo, Vitória. 
DELLA PORTA, Donatela. (2014), Mobilizing for Democracy: Comparing 1989 and 2011. Oxford, Oxford University Press.

DIANI, Mario. (2003), “Introduction: Social Movements, Contentious Actions, and Social Networks: 'From Metaphor to Substance'?", in M. Diani e D. McAdam (eds.), Social Movements and Networks: Relational Approaches to Collective Action. Oxford, Oxford University Press, pp. 1-18.

DOWBOR, Monika. (2012), A arte da institucionalização: estratégias de mobilização dos sanitaristas (1974-2006). Tese (Doutorado em Ciência Política), Universidade de São Paulo, São Paulo.

; CARLOS, Euzeneia; ALBUQUERQUE, Maria do Carmo. (2018), “As Origens Movimentistas de Políticas Públicas: Proposta Analítica Aplicada às Áreas de Criança e Adolescente, Direitos Humanos e Saúde". Lua Nova, nº 105, pp. 47-80.

EARL, Jennifer. (2004), "The Cultural Consequences of Social Movements", in D. Snow, S. Soule e H. Kriesi (eds.), The Blackwell Companion to Social Movements. Oxford, Blackwell, pp. 508-530.

GAMSON, William. (1990), The Strategy of Social Protest. Belmont, Wadsworth.

GOLDSTONE, J.A. (2003), "Bridging Institucionalized and Noninstitucionalized Politics", in J.A. Goldstone (eds.), States, Parties, and Social Movements. Cambridge, Cambridge University, pp. 1-24.

GIUGNI, Marco. (2008), "Political, Biographical, and Cultural Consequences of Social Movements". Sociology Compass, vol. 2, nº 5, pp. 1582-1600.

; PASSY, Florence. (1998), “Contentious Politics in Complex Societies: New Social Movements Between Conflict and Cooperation", in M. Giugni, D. McAdam e C. Tilly (eds.), From Contention to Democracy. Lanham, Rowman \& Littlefield, pp. 81-107.

; MCADAM, Doug; TILLY, Charles. (1999), How Social Movements Matter. Minneapolis/London, Minnesota Press.

GURZA LAVALLE, Adrian; CARLOS, Euzeneia; DOWBOR, Monika; SZWAKO, José. (2019), "Movimentos Sociais, Institucionalização e Domínios de Agência", in A. Gurza Lavalle, E. Carlos, M. Dowbor e J. Szwako (eds.), Movimentos Sociais e Institucionalização: Políticas Sociais, Raça e Gênero no Brasil Pós-Transição. Rio de Janeiro, EdUERJ, pp. 21-86.

MACIEL, Debora. (2011), “Ação Coletiva, Mobilização do Direito e Instituições Políticas: O Caso da Campanha da Lei Maria da Penha". Revista Brasileira de Ciências Sociais, vol. 26, n 77 , pp. 97-112.

MCADAM, Doug; BOUDET, Hilary. (2012), Putting Social Movements in Their Place: Explaining Opposition to Energy Projects in the United States, 2000-2005. Cambridge, Cambridge University Press.

NATALINO, Marco Antonio; ANDRADE, Carla Coelho; DUARTE, Bruno Carvalho; CASTRO, Paulo. (2009), "Constituição e Política de Direitos Humanos: Antecedentes, Trajetórias e Desafios". Políticas Sociais: Acompanhamento e Análise. Vinte Anos da Constituição Federal. IPEA, vol. 3, n 17, pp. 67-134. 
PETERSEN, Abby; WAHLSTRÖM, Mattias. (2015), “Repression. The Governance of Domestic Dissent", in D. Della Porta e M. Diani (eds.), The Oxford Handbook of Social Movements. Oxford, Oxford Press, pp. 635-652.

PICCIO, Daniela (2016), "The Impact of Social Movements on Political Parties", in L. Bosi, M. Giugni e K. Uba (eds.), The Consequences of Social Movements. Cambridge, Cambridge University Press, pp. 263-284.

POLLETTA, Francesca; JASPER, James. (2001), “Collective Identity and Social Movements”. Annual Review of Sociology, vol. 27, pp. 283-305.

RIBEIRO JUNIOR, Humberto. (2011), “As Políticas Penitenciárias e de Segurança Pública do Espírito Santo no Governo Hartung (2003-2010)". Anais do XV Congresso Brasileiro de Sociologia.

ROOTES, Christopher. (2004), Environmental Protest in Western Europe. Oxford, Oxford University Press.

; NULMAN, Eugene. (2015), “The Impacts of Environmental Movements", in D. Della Porta e M. Diani (eds.), The Oxford Handbook of Social Movements. Oxford, Oxford Press, pp. 729-742.

SOULE, Sarah; KING, Brayden. (2006), "The Stages of the Policy Process and the Equal Rights Amendment, 1972-1982". American Journal of Sociology, vol. 111, pp. 1871-1909.

SOUZA, Jaqueline Marcelino. (2014), Inclusividade e Efetividade no Conselho Estadual de Direitos Humanos do Espírito Santo (2009-2013). Dissertação (Mestrado em Ciências Sociais), Universidade Federal do Espírito Santo, Vitória.

TARROW, Sidney. (2009), O Poder em Movimento: Movimentos Sociais e Confronto Político. Petrópolis, Vozes.

TATAGIBA, Luciana; TEIXEIRA, Ana Claudia. (2016), “Efeitos Combinados dos Movimentos de Moradia sobre os Programas Habitacionais Autogestionários". Sociologia e Política, vol. $24, \mathrm{n}^{\circ} 58$, pp. $85-102$.

TAVARES, Célia Maria Vilela. (2004), Crime e Política no Espírito Santo. Dissertação (Mestrado em Ciência Política), Universidade Federal Fluminense, Niterói.

TILLY, Charles; TARROW, Sidney. (2015), Contentious Politics. $2^{\mathrm{a}}$ edição. London, Paradigm Publishers.

(2006), Regime and Repertoire. Chicago, The University of Chicago Press.

(2005), Identities, Boundaries \& Social Ties. Boulder/Londres, Paradigm Publishers.

XAVIER, Aracely. (2014), As ações, lutas, estratégias e desafios do movimento de defesa dos direitos das crianças e adolescentes no Espírito Santo. Dissertação (Mestrado em Política Social), Universidade Federal do Espírito Santo, Vitória.

WHITTIER, Nancy. (2004), “The Consequences of Social Movements for Each Other”, in D. Snow, S. Soule e H. Kriesi (eds.), The Blackwell Companion to Social Movements. Oxford, Blackwell, pp. 531-551. 


\section{DOCUMENTOS CITADOS}

ASSEMBLEIA LEGISLATIVA DO ESPÍRITO SANTO. (1994), Dossiê Gabriel Maire. Comissão Permanente de Defesa da Cidadania e Direitos Humanos, Vitória.

ASSOCIAÇÃO DE MÃES E FAMILIARES DE VÍTIMAS DE VIOLÊNCA DO ES. (2011), Dos Contêineres às Masmorras High-Tech: O Novo Sistema Prisional Capixaba - As Novas (e as Velhas) Violações de Direitos. Vitória.

BRASIL. (2010), Programa de Proteção a Crianças e Adolescentes Ameaçados de Morte: PPCAAM. Brasília: Secretaria de Direitos Humanos da Presidência da República.

(2014), 10 Anos PPDDH. Contribuições Cotidianas para a História dos Direitos Humanos no Brasil. Brasília: Secretaria de Direitos Humanos da Presidência da República.

CÂMARA FEDERAL. (2000), Relatório da CPI do Narcotráfico. Brasília.

(2009), Relatório da CPI para Apurar as Diligências nos Presídios Capixabas. Brasília.

COMISSÃO DE PROCESSOS ADMINISTRATIVOS ESPECIAIS. (1993a), Dossiê da Comissão sobre Grupo de Extermínio e Crime Organizado no Espírito Santo. Vitória.

(1993b), Relatório de Ameaças à Comissão. Vitória.

CONECTAS DIREITOS HUMANOS. (2009), Relatório Violações no Sistema Carcerário no ES. São Paulo.

CONSELHO ESTADUAL DE DIREITOS HUMANOS. (2011a), Cartilha 15 Anos em Revista. Vitória.

(2011b), Relatório sobre Tortura e Outros Tratamentos Cruéis, Desumanos e Degradantes no Espírito Santo. Vitória.

FORUM REAGE ESPÍRITO SANTO. (2002), Relatório sobre Audiência sobre a Situação dos Direitos Humanos no Espírito Santo junto à Comissão de Direitos Humanos da OEA. Vitória.

FORUM REAGE ESPÍRITO SANTO. (2003), Relatório sobre Execuções Sumárias, Extrajudiciais ou Arbitrárias. Vitória.

(2000), Relatório sobre o Crime Organizado. Vitória.

FÓRUM CONTRA A VIOLÊNCIA EM DEFESA DA VIDA. (1991), Documento sobre a Situação de Violência no Estado do Espírito Santo Entregue a sua Santidade o Papa João Paulo II. Vitória.

HUMAN RIGHTS WATCH/AMERICAS. (1994), Final Justice: Police and Death Squad Homicides of Adolescents in Brazil. Disponível em: https:/ /www.hrw.org/reports/pdfs/b/brazil/ brazil.942/braz942full.pdf. Acesso em: 4 de março de 2016.

JUSTIÇA GLOBAL. (2002), A Situação Atual da Defesa dos Direitos Humanos no Estado do Espírito Santo: Assassinatos, Ameaças de Morte, Processos Judiciais Indevidos e Pressões Institucionais Contra Defensores de Direitos Humanos. Rio de Janeiro, Vitória.

; CONECTAS DIREITOS HUMANOS; CDDH; CEDH. (2011), Violações de Direitos Humanos no Sistema Prisional do Espírito Santo: Atuação da Sociedade Civil. Rio de Janeiro, Vitória. 
Euzeneia Carlos

MINISTÉRIO DA JUSTIÇA. (2002), Relatório do Conselho de Defesa dos Direitos da Pessoa Humana (CDDPH) sobre Intervenção Federal no ES. Brasília.

. (2009), Relatório de visita ao Espírito Santo do Conselho Nacional de Política Criminal e Penitenciária (CNPCP). Brasília.

MINISTÉRIO PÚBLICO FEDERAL. (1996), Ação para a Dissolução da Scuderie Detetive Le Cocq. Vitória.

MOVIMENTO ESTADUAL DE DIREITOS HUMANOS. (1989), Relatório sobre Inquéritos Policiais de Apuração de Assassinatos. Vitória.

. (2002), Relatório da Comissão Debatedora da Intervenção Federal no ES. Vitória.

(2004), Relatório Combate à Impunidade no Estado do Espírito Santo. Vitória.

MOVIMENTO NACIONAL DE DIREITOS HUMANOS. (2003), Relatório Final da Campanha Nacional Permanente de Combate à Tortura e à Impunidade. Rio de Janeiro.

;CDDH; FÓRUM DAS ENTIDADES DO CAMPO E DA CIDADE. (1994), Relatório Acerca da Violência e Impunidade no ES. Vitória. 


\section{RESUMO}

Movimentos Sociais e Politicas Públicas: Consequências na Politica Nacional de Direitos Humanos

Este artigo analisa os resultados políticos do movimento social na política pública, especificamente as consequências do movimento de Direitos Humanos nos programas de proteção da Política Nacional de Direitos Humanos. Baseia-se em pesquisa empírica de duas décadas (1990 e 2000) do movimento de Direitos Humanos no Espírito Santo, através de duas campanhas de abrangência nacional examinadas por meio de documentos e entrevistas com ativistas: Campanha Contra a Impunidade e Corrupção e Campanha Contra as Violações no Sistema Prisional. Utiliza uma abordagem correlacional-processual para investigar as consequências do movimento social na política pública. O principal argumento é que o movimento de Direitos Humanos produziu consequências sobre a formulação e implementação da política pública que são estruturantes da Política Nacional de Direitos Humanos. Argumenta que esses resultados consistem num processo de institucionalização de direitos que configura encaixes institucionais. Adicionalmente, ressalta o papel dos repertórios de confronto como condição que favorece os resultados políticos e os mecanismos que operam na mobilização.

Palavras-chave: movimentos sociais; política pública; repertórios de confronto; encaixes institucionais; resultados políticos

\section{ABSTRACT \\ Social Movements and Public Policies: Consequences on the National Human Rights Policy}

This article analyzes the political outcomes of social movement in public policy, specifically the consequences of the human rights movement on protection programs in the National Human Rights Policy. It is based on empirical research of two decades of the human rights movement (the 1990s and the 2000s)in Espírito Santo, Brazil, focusing on two national campaigns: (i) Campaign Against Impunity and Corruption; and (ii) Campaign Against Violations in the Prison. Campaigns are examined in depth through documents and interviews with activists. A correlational-process approach is used to investigate the consequences of the social movement in public policy. The main argument is that the human rights movement produced consequences for the formulation and implementation of public policy which are structuring of the National Human Rights Policy. It also argues that these results consist of a process of the institutionalization of rights which configures institutional fit. In addition, highlight the role of the repertoire of contention as a condition which favors political outcomes and the mechanisms which operate in mobilization.

Keywords: Social Movement; Public Policy; Repertoires of Contention; Institutional Fit; Political Outcomes 


\section{RÉSUMÉ}

Mouvements Sociaux et Politiques Publiques: Conséquences sur la Politique Nationale des Droits de l'Homme

Cet article analyse les résultats politiques du mouvement social dans les politiques publiques, en particulier les conséquences du mouvement des droits de l'homme dans les programmes de protection de la Política Nacional de Direitos Humanos. Il est basé sur une recherche empirique de deux décennies (1990 et 2000) du mouvement des droits de l'homme à Espírito Santo, à travers deux campagnes nationales examinées à travers des documents et des entretiens avec des militants: Campanha Contra a Impunidade e Corrupção; e Campanha Contra as Violações no Sistema Prisional. Il utilise une approche corrélation-procédurale pour étudier les conséquences du mouvement social dans les politiques publiques. L'argument principal est que le mouvement des droits de l'homme a eu des conséquences sur la formulation et la mise-em-œuvre des politiques publiques qui structurent la Política Nacional de Direitos Humanos. Il soutient que ces résultats consistent en un processus d'institutionnalisation des droits qui configure les cadres institutionnels. De plus, il met en évidence le rôle des répertoires conflictuels en tant que condition qui affecte les résultats politiques.

Mots-clés: Mouvements sociaux; Politique publique; Répertoires de confrontation; Prises institutionnelles; Résultats politiques

\section{RESUMEN}

Morimientos Sociales y Politicas Públicas: Consecuencias en la Politica Nacional de Derechos Humanos

Aquí se analizan los resultados políticos del movimiento social en la política pública, específicamente las consecuencias del movimiento de derechos humanos en los programas de protección de la Política Nacional de Derechos Humanos. Se basa en una investigación empírica de dos décadas (1990 e 2000) del movimiento de derechos humanos en el estado de Espírito Santo, a través de dos campañas de divulgación nacional examinadas por medio de documentos y entrevistas con activistas: Campaña Contra la Impunidad y Corrupción y Campaña Contra las Violaciones en el Sistema Penal. Se utiliza un abordaje correlacional-procedimental para investigar las consecuencias del movimiento social en la política pública. El principal argumento es que el movimiento de derechos humanos produjo consecuencias sobre la formulación e implementación de la política pública que son estructurantes de la Política Nacional de Derechos Humanos. Se argumenta que esos resultados consisten em un proceso de institucionalización de derechos que configura marcos institucionales. Adicionalmente, se resalta el papel de los repertorios de confrontación como condición que afecta los resultados políticos.

Palabras clave: Movimientos Sociales; Política Pública; Repertorios de Confrontación; Marcos Institucionales; Resultados Políticos 